\title{
National school feeding program: strategies to overcome food insecurities during and after the COVID-19 pandemic
}

\author{
Ana Laura Benevenuto de Amorim 1 \\ José Raimundo Sousa Ribeiro Junior ${ }^{2}$ \\ Daniel Henrique Bandoni ${ }^{3}$ \\ ${ }^{1}$ Universidade Federal de São Paulo / Interdisciplinary Program in Health Sciences, Santos / SP - Brazil \\ ${ }^{2}$ Universidade Federal de São Paulo / Center of Practices and Research in Nutrition and Collective Food Services, Santos / SP - Brazil \\ ${ }^{3}$ Universidade Federal de São Paulo / Department of Health, Clinical Practice and Institutions, Institute of Health and Society, \\ Santos / SP - Brazil
}

\begin{abstract}
This article aims to analyze the contribution of the National School Feeding Program (PNAE), in the fight against hunger and food insecurity (FI) and to propose a set of strategies to guarantee that students will continue to receive food during the COVID-19 pandemic. Diagnosis of FI and hunger in Brazil was carried out, analyzing the weakening of Food and Nutritional Security Policies, considering the historical evolution of PNAE and its current situation, and from this analysis, a set of proposals were drawn up, assessing their impacts on the PNAE's budget. We present the following strategies for the period of school closures: distribution of meals for students, maintaining, if possible, the universal character of the policy or benefiting students from families eligible to receive Emergency Aid due to COVID-19; expand the amount transferred by the PNAE to municipalities with a low and very low Human Development Index (HDI) and; maintenance and incentive to purchase food from family farming. When schools re-open, we suggest the following strategies: FI survey among students; maintenance of the equity of the policy by expanding the transfer amount to municipalities with low and very low HDI, and; attendance of students from families in FI during the vacations.
\end{abstract}

Keywords: COVID-19; Programa Nacional de Alimentação Escolar (PNAE); school feeding; food and nutrition security.

\section{Programa Nacional de Alimentação Escolar: estratégias para enfrentar a insegurança alimentar durante e após a COVID-19}

Este artigo tem como objetivo analisar a contribuição do Programa Nacional de Alimentação Escolar (PNAE) para o enfrentamento da fome e da insegurança alimentar (IA), ao propor um conjunto de estratégias para que o PNAE possa garantir a alimentação dos escolares neste momento de crise. Realizamos um diagnóstico da IA e da fome no Brasil, analisamos o processo de enfraquecimento das políticas de segurança alimentar e nutricional, consideramos a evolução histórica do PNAE e sua situação atual e, com base nessas reflexões, apresentamos um conjunto de propostas, avaliando seus impactos no orçamento destinado ao PNAE. Apresentamos as seguintes estratégias para o período em que as aulas estiverem suspensas: distribuição de kits ou refeições para escolares, se possível mantendo o caráter universal da política ou beneficiando estudantes das famílias elegíveis para receber o Auxílio Emergencial; ampliar o valor repassado pelo PNAE para os municípios com Índice de Desenvolvimento Humano (IDH) baixo e muito baixo; manter e incentivar a aquisição de alimentos da agricultura familiar. Após o retorno das aulas, sugerimos as seguintes estratégias: levantamento da IA entre os estudantes, manutenção da equidade da política por meio da ampliação do valor do repasse para municípios com IDH baixo e muito baixo, além de atendimento dos escolares de famílias em IA durante as férias e o recesso escolar.

Palavras-chave: COVID-19; Programa Nacional de Alimentação Escolar (PNAE); alimentação escolar; segurança alimentar e nutricional. 


\section{Programa Nacional de Alimentación Escolar: estrategias para enfrentar la inseguridad alimentaria durante y después de la COVID-19}

Este artículo tiene como objetivo analizar la contribución del Programa Nacional de Alimentación Escolar (PNAE) en la lucha contra el hambre y la inseguridad alimentaria (IA) y proponer un conjunto de estrategias para que el PNAE pueda garantizar la alimentación de los estudiantes en este momento de crisis. Para tanto, realizamos un diagnóstico de la IA y el hambre en Brasil, analizamos el debilitamiento de las políticas de seguridad alimentaria y nutricional, consideramos la evolución histórica del PNAE y su situación actual. Con base en estas reflexiones, presentamos un conjunto de propuestas evaluando sus impactos en el presupuesto asignado al PNAE. Presentamos las siguientes estrategias para el período en que las clases estén suspendidas: distribución de kits de alimentos o comidas a los alumnos, manteniendo, si fuera posible, el carácter universal de la política o beneficiando a los estudiantes de familias elegibles para recibir la Ayuda de Emergencia debido a la COVID-19; aumentar el monto transferido por el PNAE a los municipios con un índice de desarrollo humano (IDH) bajo y muy bajo y; mantener e incentivar la compra de alimentos a la agricultura familiar. Después del regreso de las clases, sugerimos las siguientes estrategias: encuesta de IA entre los estudiantes; mantenimiento de la equidad de la política mediante el aumento del monto de la transferencia a municipios con IDH bajo y muy bajo; y asistencia a los estudiantes de familias en situación de IA durante las vacaciones y el receso escolar.

Palabras clave: COVID-19; Programa Nacional de Alimentação Escolar (PNAE); alimentación escolar; seguridad alimentaria y nutricional.

\section{INTRODUCTION}

One of the main characteristics of policies related to ensuring food security in Brazil has been discontinuity. Few of them have not been policies associated with specific administrations and have become state policies covered by the Constitution, as is the case of the National School Lunch Program (PNAE) (Vasconcelos, 2005).

Originally known as the National School Lunch Campaign, in its first years the PNAE provided assistance and sought to reduce malnutrition by offering food supplements focused on the country's poorest areas (Peixinho, 2013). The Federal Constitution of 1988, in universalizing the right to a school lunch ${ }^{1}$ and defining what should be guaranteed by the three levels of government, was the decisive force in the transformation of the PNAE into a state policy. Since then other laws have been responsible for the growth and strengthening of the program which today serves approximately 40 million students all over the country, and seeks to contribute to biopsychosocial development, learning and school performance, and the formation of healthy food habits in students, through food and nutrition education activities and the offering of meals which meet nutritional needs during school hours (Law no 11,947 of 2009).

Studies point to the influence of socioeconomic aspects in the adherence of school lunch programs, which indicates its importance especially for certain groups of students. Authors of various studies have identified that the consumption of lunches at school is greater for boys who live in the North, the Northeast, and Mid-West, in rural areas, and those who are black or brown; it is lower in the state of São Paulo, in metropolitan areas, and tends to diminish with age and increase with per capita household income (Hoffmann, 2012). Another finding is that students who are male and brown, and do not live in the capital and have mothers with little schooling, are more likely to consume school lunches regularly (Locatelli, Canela, \& Bandoni, 2017).

\footnotetext{
${ }^{1}$ With the passage of the Federal Constitution, elementary students acquired the right to school lunches. Only in 2009, with Law $\mathrm{n}^{\mathrm{o}} 11,947$, were school lunches provided for all students matriculated in primary education.
} 
At the moment, due to social isolation to combat the COVID-19 pandemic, the PNAE finds itself facing an enormous challenge to continue to provide school lunches. In many cases, the suspension of classes in public schools has signified the interruption or reduction of access to food, which affects not only family budgets but also harms the quantity and quality of student food.

Thus, we understand that the PNAE plays an extremely important role in fighting food insecurity (FI) and hunger during the pandemic, in such a way that we are proposing a series of strategies to be adopted within the scope of this program. To lay the groundwork for our proposals, we begin with an exposition presenting the diagnosis of FI and hunger in Brazil. Then, we will analyze the process of weakening food and nutrition security policies. This will be followed by the evolution of the PNAE and its current situation. Finally, we propose a group of strategies so that the PNAE can ensure the providing of school lunches to students during and after this period of social isolation.

\section{FOOD INSECURITY AND HUNGER IN BRAZIL}

One of the first challenges that presents itself in dealing with the problem of hunger and food insecurity is the quantification of the problem itself. Various definitions and methodologies have produced distinct, and at times, contradictory data. Since the 1970s, the United Nations Food and Agriculture Organization (FAO) has used the prevalence of malnutrition indicator to estimate the number of hungry people in the world. Even though this is an important measure to identify more serious cases of hunger, this indicator has proved inadequate in capturing hunger to its full extent.

Thus, beginning in the 1980s, various researchers sought to develop a new methodology to quantify hunger (Radimer, Olson, Green, Campbell, \& Habicht, 1992; Wehler, Scoot, \& Anderson, 1992), which led to the development of the Children's Food Security Scale, adopted by the Food and Nutrition Service of the United States Department of Agriculture (USDA) in 1995 (Bickel et al., 2000). In 2003, Brazil began translating and adapting the Children's Food Security Scale to contribute to the recently launched Zero Hunger Program, through the elaboration of "direct quantification indicators for the population subject to varying degrees of food insecurity, which are also appropriate in the evaluation of its actions and strategies" (Segall-Correa \& Marin-Leon, 2009).

Once validated, the Brazilian Food Insecurity Scale (EBIA) was used by the Brazilian Institute of Geography and Statistics (IBGE) to supplement the National Food Security Household Survey (PNAD) in 2004, 2009 and 2013, providing the most reliable data which we have on the access to food in Brazil. The production of this data provided a better understanding of the profile of food insecurity in this country, both in terms of its magnitude and severity as well as its principal determinants and spatial distribution.

Between 2004 and 2013, the number of dwellers in households in a situation of food insecurity went from a bit over 73 million (39.8\% of the population) to approximately 52 million (25.8\%). If we examine the data related to households in a situation of moderate and grave FI, which indicate the quantitative restriction of food, the reduction of people living in hunger decreased from around 35.8 million (19.5\%) to 17.5 million people ([8.7\%] IBGE, 2014). 
The data demonstrates that the food situation of Brazilians improved during this period, but it also reveals that a significant portion of the population still has great difficulty in feeding itself properly. Data from 2013 indicates that in $80 \%$ of the households in situations of FI, the monthly per capita household income is less than the minimum wage. In addition, $34.2 \%$ of those 4 years old or less and $33.2 \%$ of those between the ages of 5 and 17 displayed FI, which reinforces the importance of the PNAE (IBGE, 2014).

\section{THE WEAKENING OF FOOD AND NUTRITION SECURITY POLICIES}

If the food situation of the Brazilian population in 2013 required attention from the government, the situation only became worse beginning in 2015. From then on, there was greater unemployment and underemployment, which affected $6.9 \%$ and $24.6 \%$ of the population respectively in 2018 (IBGE, 2019). Accordingly, between 2014 and 2018 the number of people living below the poverty line- that is, less than 5.5 dollars a day - went from $22.8 \%$ to $25.3 \%$ ( 52.5 million people), and the proportion of people living below the extreme poverty line - those who live on less than 1.9 dollars per day - went from $4.5 \%$ to $6.5 \%$ of the population ([13.5 million people] IBGE, 2019). This scenario demands the expansion and strengthening of food and nutrition security policies (SAN) to guarantee the Human Right to Adequate Food ([HRAF] Law no 11,346, 2006).

What has been observed in recent years, however, has been the weakening of these policies by the federal government. The processes below illustrate this weakening:

1. Disarticulation of the National System of Food and Nutrition Security (Sisan), through the gradual abandonment of the National Board of Food and Nutrition Security (Consea) and the Interministerial Chamber of Food and Nutrition Security (Caisan). Essential pieces to the functioning of the Sisan, both have formally been eliminated through a provisional measure signed by President Jair Bolsonaro.

2. The absence of the National Conference on Food and Nutrition Security, responsible for indicating the guidelines and priorities of the National Food Security Policy (Plansan). Effectively, the federal government has not elaborated the plan envisioned for the period of 2020-2023.

3. The Bolas Familia Program (BFP), the main income transfer program in the country, has had its budget and number of employees reduced. Between December 2018 and December 2019, there was a reduction of 1 million in the total of families who benefit from the program (going from 14.1 to 13.1 million), and the original budget for 2020 pointed to a continuation of this process with a decrease from $\mathrm{R} \$ 32.5$ billion to $\mathrm{R} \$ 29.5$ billion. $^{2}$

Within the process of weakening the SAN policies, there have also been budgetary cuts in other important programs, such as the Food Acquisition from Family Farming Program (PAA), and the reduction in Conab's strategic stock of food, essential to guaranteeing the Lowest Price Guarantee Policy which protects rural producers. In addition, this stock is useful in crisis situations and can be used to provide food to schools and food donations for those in need.

${ }^{2}$ Retrieved from https://www2.camara.leg.br/orcamento-da-uniao/raio-x-do-orcamento-previdencia/raio-x-do-orcamento-ploa-2020 


\section{THE EVOLUTION OF THE NATIONAL SCHOOL LUNCH PROGRAM}

Since the adoption of the Federal Constitution in 1988, the evolution of the PNAE has been marked by advances that deserve attention. The first of these was the decentralization of its management through Law n ${ }^{\circ} 8,913$ of 1994. From this point onward, the Ministry of Education (MEC) established agreements with states and municipalities - executing entities (ExEs) - to distribute financial resources, making it possible to regularize the providing of the food and improve the quality of the lunches. Currently, the PNAE is managed by the National Fund for the Development of Education (FNDE), an autonomous body linked to the MEC, which distributes to ExEs a given fixed value for the number of students for each type of education in accordance with the school year, considered to be 200 days of class.

In 2000, the PNAE instituted social participation through the School Lunch Boards (CAE), which are mandatory in all of the ExEs and have a role in accompanying and supervising the execution of the program (Provisional Measure $n^{\circ}$ 1,979-19, 2000).

Other significant advances have been the revision of the legal framework of the PNAE (Law $\mathrm{n}^{\circ} 11,947$ of 2009), which universalized the program to ensure the providing of healthy and adequate school lunches for all students matriculated in primary education. In addition, it established that at least $30 \%$ of its financial resources should be used for the acquisition of food directly from family farms, prioritizing agrarian reform settlements, traditional indigenous and quilombo communities, as well as organic and/or agro-ecological food. This provision is designed to promote economic development, fight inequality, minimize rural exoduses, and ensure the proper functioning of the SAN in the fields (Assis, Priore, \& Franceschin, 2017). ${ }^{3}$

Finally, over the past two decades, there has been an expansion in the federal resources utilized for the PNAE, in accordance with the increase in the number of students served. However, there remains the challenge of guaranteeing healthy and varied food with a value which varies from $\mathrm{R} \$ 0.32$ to $\mathrm{R} \$ 2.00$ per capita per day (Resolution $\mathrm{n}^{\circ} 1$ of 2017). The PNAE expects this value to be supplemented by state and municipal governments, but the country's economic, social and regional inequalities have made the execution of this policy unequal, even though it is universal. Executing Entities with fewer resources tend to spend less on these supplements, which often makes it inviable to provide food as envisioned by the law.

\section{THE PNAE IN THE FACE OF THE CORONAVIRUS PANDEMIC}

As part of the strategy to combat COVID-19 in Brazil, beginning on March 23, 2020 municipal, state and federal schools suspended classes and in-person activities throughout the country. Even though this was a predictable measure, given that other countries have faces similar situations, when it occurred, the FNDE did not provide an orientation for the ExEs as to how to proceed in the supplying of school lunches.

\footnotetext{
${ }^{3}$ Despite the advance in the purchases of food from family farms, data published by the FNDE indicates that municipalities still have not managed to achieve the level of $30 \%$ envisioned by the law. The figure in 2017 was only $17.46 \%$ (FNDE, 2020).
} 
Given the urgency of the situation, managers adopted distinct measures to continue to supply school lunches and, without a legal foundation, they found it was impossible to use PNAE resources for these actions.

The legal foundation came only on April 7 through Law n 13,987, which authorized "in an exceptional nature, during the period of suspended classes due to this public emergency, the distribution of food acquired with PNAE resources to the parents or guardians of primary education public school students." Two days later, the FNDE published a resolution about the execution of the PNAE during this public calamity, accompanied by a booklet designed to orient managers in terms of how to deal with the crisis (Resolution n² 2, 2020; Mapa \& MEC, 2020).

From this point on, two concerns have emerged in relation to the functioning of the PNAE during and after this public calamity. The first concerns the universal nature of the program, because the first article of Resolution 2 gives the ExEs autonomy to define the criteria for those eligible to receive the food or lunches acquired with PNAE resources (Resolution $n^{\circ} 2,2020$ ). It is understood that this position was necessary, given the difficulty of preparing kits for all students with just the resources transferred exclusively by the federal government. However, in a few cases, the established criteria have been restrictive, depriving many students who also need this food. This is the case with those ExEs which have restricted food assistance just to those families who take part in the Bolsa Familia Program.

The second concern is related to the maintaining the acquisition of food from family farms and the quality of the supplied food. Despite the difficulties imposed by the crisis, the PNAE should continue to focus on offering healthy and varied food with restrictions and prohibitions of certain food groups. The purchase of food from family farms, essential to the promotion of the food security of producers and consumers (students) has consolidated over the past 10 years and plays a central role, and this should be valued.

\section{STRATEGIES TO COMBAT FOOD INSECURITY DURING (AND AFTER) THE CORONAVIRUS PANDEMIC}

The PNAE plays an important role in the guarantee of the HRAF of students enrolled in the public school system which represents $80 \%$ of all primary education. This system is very extensive and the program already has the infrastructure necessary to make its strategic goals viable, which in turn makes it possible for those who need these invested resources to receive them quickly.

It's also important to emphasize that the public school system covers the entire territory of the country which is characterized by significant differences and inequalities. Thus, it is not recommended that the ExE strategies be used. The FNDE should guarantee that local managers, in contact with the CAEs, should have a legal foundation and financial resources to define strategies which are more appropriate for each context.

Given this complex scenario, we have divided our strategies into two groups. 


\subsection{Strategies during the period in which classes are suspended}

\subsubsection{Supplying of food kits and/or lunches}

Resolution 2 envisions that the resources of the PNAE can be used to offer food kits and/or (takeout) lunches during this social isolation period. For both actions, strategies to minimize crowds and the exposure of workers should be followed (Mapa \& MEC, 2020).

Lunches tend to have a lower unit cost and can be offered daily to students, but they require the daily mobilization of those who prepare the food and at least one member of the student's family. The food kits, on the other hand, can be offered weekly or monthly, which reduces the amount of travel required. However, their cost tends to be higher, which is a restrictive factor in terms of the quality and quantity of food offered for the students who need food.

The choice of these modes may involve a group of criteria based on the local reality, given that each of them presents distinct advantages and disadvantages.

We propose the maintaining of the universality of the program, but we understand that in the actual situation some managers will have to prioritize service for a portion of the students. In this case, we suggest the adoption of Emergency Aid - a financial benefit designed for families in the Unified Registration Database for social programs, informal workers, individual micro-entrepreneurs, the self-employed and the unemployed - being an already existing database which includes more families in a situation of social vulnerability.

\subsubsection{Emergency aid for municipalities with a low or very low Human Development Indices (HDI)}

Considering that ExEs exist which do not have the resources to supplement the money distributed by the federal government, and that, in general, this occurs in locations in which school lunch programs play an important role in guaranteeing the HRAF, we suggest that transfers from the federal government to municipalities with a low HDI (between 0.500 and 0.599 ) and very low HDI (up to 0.499) should be equivalent to the per capita value transferred to traditional (indigenous and quilombo) communities - between $\mathrm{R} \$ 0.64$ and $\mathrm{R} \$ 1.07$, depending on the mode of teaching and the school period. In Brazil, there are 1,399 municipalities with an HDI below 0.600 (and 32 classified as very low), mainly centered in rural areas of the Northeast. According to the 2019 School Census, these municipalities serve $6,272,164$ students (17.1\% of all primary education students, PNUD, 2013).

In this manner, with an increase of just $3 \%$ in the total program budget (Table 1), these municipalities will have more resources so that the distribution of kits or lunches will be maintained for all students. 
Data about school lunches and students

Total resources used by the PNAE in $2019(\mathrm{R} \$)^{*}$

Total number of students in primary education **

Total number of students in primary education in municipalities with a Low or Very Low HDI **

Average value of financial assistance by the FNDE for the PNAE, per day per primary education student (R\$)

Financial impact of the increase in the daily value per student of the PNAE, destined for municipalities with low and very low HDI $(\mathrm{R} \$)^{\mathrm{t}}$

Financial impact of the increase in the daily value per student of the PNAE and the expansion of the benefit for the entire year, destined to municipalities with low and very low $\mathrm{HDI}(\mathrm{R} \$)^{\mathrm{H}}$
Numbers

$3,950,473,553.79$

$36,611,223$

$6,272,164$

0.54

$125,443,280.00$

$787,783,798.40$

PNAE - National School Lunch Program / FNDE - National Fund for the Development of Education of the Ministry of Education.

* Data extracted from the information system regarding the liberation of FNDE resources (Accessed at https://www.fnde.gov.br/sigefweb/ index.php/liberacoes).

** Data extracted from the School Census of 2019 (Accessed at http://portal.inep.gov.br/censo-escolar).

$* * *$ Data obtained from the Brazilian Human Development Index (PNUD, 2013).

$¥$ Increase in the distribution per student of $\mathrm{R} \$ 0.64$ per day for school days.

\# Increase in the distribution per student of $\mathrm{R} \$ 0.64$, per day for the entire year.

Source: Elaborated by the authors.

Emergency aid for municipalities with low and very low HDI values benefit just small municipalities and do not consider pockets of poverty in metropolitan areas. In weighing the need to increase the distribution to all municipalities with students in situations of FI - as we propose in the strategies to be implemented after the return to classes - it is necessary to highlight that large municipalities with higher HDI values have the greatest tax revenues, and as a result greater budgetary availability of resources to complement the resources that come from the PNAE (Castro, Guimarães, Paula, Souza, \& Fully, 2018).

\subsubsection{Maintenance and incentives for acquiring food from family farms}

Studies indicate that the inclusion of FA in the PNAE has resulted in an increase in family income, with the guarantee of market access and the flow of production, which have positively affected the SAN of farmers (Assis, Priore, \& Franceschin, 2017). In addition, FA products contribute to the quality of school lunches because they consist of in natura food that is minimally processed (Teo, 2018). The FNDE itself is concerned with this population at the moment, and the Booklet containing PNAE Orientation during the pandemic enumerates new forms of execution, presented as a strategy to preserve the continuity of family farming and the elaboration of electronic public audiences. There is also an orientation to maintain contracts signed with family farmers, respecting the already stipulated delivery calendar, in order not to harm these farmers (Mapa \& MEC, 2020).

It should also be pointed out that incentives for acquiring food from FA with PNAE resources also depends on coordinating with governmental actions to overcome the difficulties faced by the 
PAA. Siambuichi, Galindo, Oliveira, and Moura (2014) name a few measures which can be taken to strengthen the FA public purchase market: the improving of the structure of support logistics for these purchases (transport, processing and storage), the promotion of continual technical assistance which supplies support to the planning of the family production unit in an integrated manner and the guarantee of credits which are appropriate to the needs of small producers. These actions can and should go beyond the pandemic, contributing to the expansion of FA purchases in the program.

\subsection{Strategies to be implemented after the return to classes}

\subsubsection{Surveying Fl among students}

During this time of crisis, the importance of data is even more evident in order to guide governmental actions. Thus, we suggest that the short version of the EBIA be applied when students matriculate/ rematriculate. This version contains 5 easy self-applied questions that permit a diagnosis of student families with food and nutrition insecurity (Santos et al., 2014). It is suggested that this data be declared for schools of all ages, together with the school census, a measure which would be simple and would have no impact on cost, making it possible to diagnose the proportion of families with FI per school. It should be emphasized that directly measured scales of food insecurity, such as the EBIA, provide strategic information for the management of social policies and programs on a national and municipal level, which makes it possible to both identify and quantify the social groups at risk of food insecurity as well as its determinants and consequences (Traldi \& Almeida, 2012).

\subsubsection{Increase of the per capita value distributed}

The data obtained with the application of the EBIA makes it possible to elaborate a diagnostic to evaluate and improve policy, as well as help decision-making at other moments of crisis. We suggest an increase in the daily per capita value for each student in a situation of FI, increasing equality within the PNAE. We recommend the utilization of the same value distributed currently to indigenous and quilombo students - R $\$ 0.64$ for half-day students $\mathrm{R} \$ 1.07$ for full-day students.

With FI data each state and municipality will be able to direct these complementary values towards schools with higher indices of students in this situation.

\subsubsection{Serving students during school vacation and recess}

PNAE resources do not envision the providing of school lunches during periods of recess and vacation. The announcement of the suspension of classes due to the coronavirus pandemic has led to the interruption of the supplying of school lunches for many families, worsening the situation of food insecurity.

The increase in unemployment and poverty as a result of the pandemic will increase the number of FI households. Thus, we propose the supplying of student lunches during vacation and recess after the end of the pandemic. If this is done, FI surveys for students can determine which families are eligible to receive this increase. Without these surveys, we propose supplying all the schools in municipalities with low and very low HDIs. This expansion of days will cost the PNAE budget approximately R $\$ 788$ million, roughly $20 \%$ of the budget of the entire 2019 program (Table 1 ). 
The way to provide school lunches during school vacations/recess will be the choice of the ExEs' management, and may be in the form of food kits or the maintenance of a daily lunch at school. This action may reframe the role of the school in relation to the community.

\subsubsection{Maintenance of the equality of the PNAE}

We propose that Emergency Aid for municipalities with low and very low HDIs be maintained after the pandemic, guaranteeing that they continue to receive per capita values equivalent to those transferred to traditional communities, and therefore increasing the program's equality. This action should be maintained while there is no FI data available for the municipalities and the schools.

\section{CONCLUSION}

The PNAE can be considered one of the most successful public policies in the country. At a cost of little over a hundred reais per student, it directly benefits over 40 million students with one or more daily meals. Thus, the program faces many challenges in fulfilling its objectives and guidelines, including the guaranteeing of food and nutrition security for students.

Since the beginning of the pandemic, many states and municipalities have executed the PNAE in a manner that recalls the beginning of the program, when just certain groups were served, which reinforced its assistentialist nature.

Our proposal, on the contrary, is based on the right to school lunches for all primary education students, which was won a little over a decade ago. Some measures are necessary to ensure the equality of the program during the pandemic, given that the economic and social inequalities between (and within) states and municipalities are an obstacle to the fulfilling of the PNAE's guidelines.

The proposal which we are presenting is not meant to overcome all the challenges to guaranteeing school and nutrition security for families with school age children. It has been elaborated based on the current moment which we are living through, marked by the pandemic and by the public calamity and economic crisis that have resulted from it. The intent of our exposition has been to demonstrate how instruments such as food and/or lunch kits, emergency aid to low and very low HDI municipalities, incentives for the purchasing of FA food, FI surveys for students and the increase in the value distributed to students in this situation, and the expansion of supplying lunches to school vacations and recesses make it possible to increase equality within this program in an agile and appropriate manner.

The need for social isolation also demonstrates that the expansion of access to food beyond school days, even though it will increase the costs of the PNAE, has great potential to effectively promote food and nutrition security for children and adolescents throughout the country.

In this manner, we understand that the challenges imposed by the pandemic (and their economic and social consequences) for the execution of the PNAE should also be taken as an opportunity to broaden and deepen the debate about the meaning and significance of school lunches in a country with high indices of food insecurity. 


\section{REFERENCES}

Assis, S. C. R, Priore, S. E., \& Franceschin, S. C. C. (2017). Impacto do Programa de Aquisição de Alimentos na segurança alimentar e nutricional dos agricultores. Ciências \& Saúde Coletiva, 22(2), 617-626.

Bickel, G., Nord, M., Price, C., Hamilton, W., \& Cook, J. (2000). Guide to measuring household food security, Revised 2000. Alexandria, VA: USDA/Food and Nutrition Service.

Castro, A. V., Guimarães, A. A. B, Paula, J. V, Souza, S, M., \& Fully, R. M. P. (2018). A influência da arrecadação própria municipal sobre o IDH dos municípios mineiros. Revista Científica Doctum Multidisciplinar, 1(1), 1-25.

Fundo Nacional de Desenvolvimento da Educação. (2020). Alimentação escolar: consultas. Dados da Agricultura Familiar. Retrieved from http://www. fnde.gov.br/index.php/programas/pnae/pnaeconsultas/pnae-dados-da-agricultura-familiar

Hoffmann, R. (2012). Determinantes do consumo da merenda escolar no Brasil: análise dos dados da PNAD de 2004 e 2006. Segurança Alimentar e Nutricional, 19(1), 33-45.

Instituto Brasileiro de Geografia e Estatística. (2014). Pesquisa Nacional por Amostra de Domicílios: Segurança Alimentar (2013). Rio de Janeiro, RJ: IBGE.

Instituto Brasileiro de Geografia e Estatística. (2019). Síntese dos indicadores sociais: uma análise das condições de vida da população brasileira. Rio de Janeiro, RJ: IBGE.

Lei $n^{\circ}$ 8.913, de 12 de julho de 1994. (1994). Dispõe sobre a municipalização da merenda escolar. Brasília, DF. Retrieved from www.planalto.gov.br/ccivil_03/ Leis/L8913.htm

Lei $n^{\circ} 11.346$, de 15 de setembro de 2006. (2006). Cria o Sistema Nacional de Segurança Alimentar e Nutricional (Sisan) com vistas a assegurar o direito humano à alimentação adequada e dá outras providências. Brasília, DF. Retrieved from http://www.planalto.gov.br/ccivil_03/_Ato20042006/2006/Lei/L11346.htm

Lei $n^{\circ} 11.947$, de 16 de junho de 2009. (2009). Dispõe sobre o atendimento da alimentação escolar e do Programa Dinheiro Direto na Escola aos alunos da educação básica. Brasília, DF. Retrieved from http://www.planalto.gov.br/ccivil_03/_Ato20072010/2009/Lei/L1 1947.htm

Lei $n$ 13.987, de 7 de abril de 2020. (2020). Altera a Lei $\mathrm{n}^{\circ} 11.947$ de 2009 para autorizar, em caráter excepcional, durante o período de suspensão das aulas em razão de situação de emergência ou calamidade pública, a distribuição de gêneros alimentícios adquiridos com recursos do PNAE aos pais ou responsáveis dos estudantes das escolas públicas da educação básica. Brasília, DF. Retrieved from http://www.planalto.gov.br/ccivil_03/_ ato2019-2022/2020/lei/113987.htm

Locatelli, N. T., Canella, D. S., \& Bandoni, D. H. (2017). Fatores associados ao consumo da alimentação escolar por adolescentes no Brasil: resultados da PeNSE 2012. Caderno de Saúde Pública, 33(4), e00183615.

Medida Provisória no 1.979-19, de 2 de junho de 2000. (2000). Dispõe sobre o repasse de recursos financeiros do Programa Nacional de Alimentação Escolar, institui o Programa Dinheiro Direto na Escola e dá outras providências. Brasília, DF.

Ministério da Agricultura, Pecuária e Abastecimento e Ministério da Educação. (2020). Orientações para a execução do PNAE Durante a situação de emergência decorrente da Pandemia do Coronavírus (covid-19). Brasília, DF: Author.

Peixinho, A. M. L. (2013). A trajetória do Programa Nacional de Alimentação Escolar no período de 2003-2010: relato do gestor nacional. Ciência \& Saúde Coletiva, 18(4), 909-916.

Programa das Nações Unidas para o Desenvolvimento. (2013). Indice de Desenvolvimento Humano Municipal Brasileiro. Brasília, DF: PNUD, IPEA, FJP.

Radimer, K. L., Olson, C. M., Greene, J. C., Campbell, G. C., Habicht, J. P. (1992). Understanding hunger and developing indicators to assess it in women and children. Journal of Nutrition Education, 24(1), 36S-44S.

Resolução CD/FNDE/MEC no 1 , de 8 de fevereiro de 2017. (2017). Altera o valor per capita para oferta da alimentação escolar do Programa de Alimentação Escolar (PNAE). Brasília, DF.

Resolução CD/FNDE/MEC no 2, de 9 de abril de 2020. (2020). Dispõe sobre a execução do Programa Nacional de Alimentação Escolar (PNAE) durante 
o período de estado de calamidade pública, reconhecido pelo Decreto Legislativo $\mathrm{n}^{\circ} 6$, de 20 de março de 2020, e da emergência de saúde pública de importância internacional decorrente do novo coronavírus (Covid-19). Brasília, DF.

Sambuichi, R. H. R., Galindo, E. P., Oliveira, M. A. C., \& Moura, A. M. M. (2014). Compras públicas sustentáveis e agricultura familiar: a experiência do Programa de Aquisição de Alimentos (PAA) e do Programa Nacional de Alimentação Escolar (PNAE). In R. H. R. Sambuichi, E. P. Galindo, M. A. C. Oliveira, \& A. M. M. Moura. (Orgs.), Políticas agroambientais e sustentabilidade: desafios, oportunidades e lições aprendidas. Brasília, DF: Instituto de Pesquisa Econômica Aplicada.

Santos, L. P., Lindemann, I. L., Mottal, J. V. S, Mintem, G., Benderl, E., \& Gigante, D. P. (2014). Proposta de versão curta da Escala Brasileira de Insegurança Alimentar. Revista de Saúde Pública, 48(5),783-789.

Segal-Corrêa, A. M., \& Marin-Leon, L. (2009). A segurança alimentar no Brasil: proposição e usos da Escala Brasileira de Medida da Insegurança Alimentar (Ebia) de 2003 a 2009. Segurança Alimentar e Nutricional, 16(2), 1-19.

Teo, C. R. P. A. (2018). The partnership between the Brazilian School Feeding Program and family farming: a way for reducing ultra-processed foods in school meals. Public Health Nutricion, 21(1), 230-237.

Traldi, D. R. C., \& Almeida, L. L. M. C. (2012). Políticas públicas de transferência de renda e a questão da segurança alimentar dos beneficiários: efetividades e entraves do Programa Bolsa Família. Politica \& Sociedades, 11(21),137-171.

Vasconcelos, F. (2005). Combate à fome no Brasil: uma análise histórica de Vargas a Lula. Revista Nutrição, 4(18), 439-457.

Wehler, C. A., Scoot, R. I., \& Anderson, J. J. (1992). The community childhood hunger identification project: a model of domestic hunger-demonstration project in Seattle, Washington. Journal of nutrition education, 24(1), 29S-35S.

\section{Ana Laura Benevenuto de Amorim}

https://orcid.org/0000-0003-0745-8201

Nutritionist; Ph.D. Student in the Interdisciplinary Program of Health Sciences at the Federal University of São Paulo (UNIFESP), São Paulo Coastal Campus. E-mail: analauraba@hotmail.com

\section{José Raimundo Sousa Ribeiro Junior}

https://orcid.org/0000-0002-6502-616X

Visiting Professor at the Federal University of São Paulo (UNIFESP) at the Center of Practices and Research in Nutrition and Collective Food Services (CPPNAC). E-mail: sousaribeirojunior@gmail.com

\section{Daniel Henrique Bandoni}

https://orcid.org/0000-0003-1638-1437

Associate Professor for the Nutrition Major at the Federal University of São Paulo (UNIFESP) through the Department of Health, Clinical Practice and Institutions within the Institute of Health and Society, São Paulo Coastal Campus. E-mail: danielbandoni@gmail.com 